Article

\title{
Social Acceptance of Forest-Based Bioeconomy-Swedish Consumers' Perspectives on a Low Carbon Transition
}

\author{
Emil Nagy*(D), Carolina Berg Rustas and Cecilia Mark-Herbert (D) \\ Department of Forest Economics, Swedish University of Agricultural Sciences, 75007 Uppsala, Sweden; \\ carolinabergrustas@gmail.com (C.B.R.); cecilia.mark-herbert@slu.se (C.M.-H.) \\ * Correspondence: emil.nagy@slu.se; Tel.: +46-70-385-6934
}

Citation: Nagy, E.; Berg Rustas, C.; Mark-Herbert, C. Social Acceptance of Forest-Based Bioeconomy-

Swedish Consumers' Perspectives on a Low Carbon Transition.

Sustainability 2021, 13, 7628

https://doi.org/10.3390/su13147628

Academic Editor: Luis Jesús Belmonte-Ureña

Received: 18 May 2021

Accepted: 5 July 2021

Published: 8 July 2021

Publisher's Note: MDPI stays neutral with regard to jurisdictional claims in published maps and institutional affiliations.

Copyright: (C) 2021 by the authors. Licensee MDPI, Basel, Switzerland. This article is an open access article distributed under the terms and conditions of the Creative Commons Attribution (CC BY) license (https:/ / creativecommons.org/licenses/by/ $4.0 /)$.

\begin{abstract}
The concept of the bioeconomy is associated with sustainable development changes and involves transitions in both production and consumption within systems. Many of these transitions relate to using renewable resources, like forest biomass, to meet basic needs, such as food, energy and housing. However, consumers must become aware of the forest-based bioeconomy so that they can contribute to the transition. This study aims to contribute to an understanding of this matter that may lead to social acceptance of the forest-based bioeconomy and, in particular, to Swedish consumer awareness of the concept and of a particular product (wooden multi-story buildings) representing the forest-based bioeconomy. The results show consumer awareness of forest sequestration capacity but less awareness of the connection to the forest-based bioeconomy and the role of wooden multi-story buildings. The results indicate a slow transition that is hindered by path dependence and limited comprehension among consumers of the effects of their choices for a forest-based bioeconomy. This study provides valuable insights for future studies of how consumer awareness and social acceptance of the forest-based bioeconomy are interconnected.
\end{abstract}

Keywords: consumers; citizens; forest-based bioeconomy; low carbon transition; perceptions; wooden multi-story buildings

\section{Introduction}

During recent decades, there has been a rapid acceleration in global greenhouse gas emissions [1]. Scientists, societies and politicians around the world agree that human activities are contributing to global warming and that actions need to be taken. One example of such action is the Paris Agreement, ratified in November 2016 [2], which stresses the importance of low carbon solutions [3]. To fulfil the goals of the Paris Agreement, substantial low carbon transitions have to take place [4].

Low carbon transitions are seen as substantial changes in the systems that serve society, so that these systems have less impact on the climate. Such systems include transportation, energy, agriculture and housing. Low carbon transitions in these systems would mean increasing energy efficiency and/or using fewer resources or renewable resources [5]. The feasibility of low carbon transitions can be studied by applying socio-technical transition (STT) theory. It can be used to assess the socio-political feasibility, social acceptance and legitimacy of various low carbon options by analysing the interpretations, strategies and resources of different social groups [5] (p. 580).

\subsection{Bioeconomy and Forest-Based Bioeconomy}

Socio-technical transition theory provides information about how different actors influence the implementation of technical change, in this case specific low carbon options. One example of a low carbon transition that has not previously been studied using STT theory is the bioeconomy, or bio-based economy.

The bioeconomy is described as: 
- A system that relies on biological processes where resources in production are reused [6];

- Part of societal transformation [7];

- An area for system innovation and transformation to the use of new technologies and materials [6].

From a practical perspective, the bioeconomy means using renewable bio-based materials, for example forest biomass, instead of fossil-based materials as part of sustainable development to reduce the greenhouse gas effect $[6,8,9]$. There is a difference between the bioeconomy, which is generally perceived as a sector, and the "bio-based economy", which refers to a shift in the conventional economy [10]. Thus, the bioeconomy primarily focuses on parts of the economy that involve biotechnical and life science elements, while the bio-based economy describes an economy that mainly uses biomass resources rather than fossil-based resources. One example of the latter is the forest-based bioeconomy (FBB), in which forest resources are the primary biomass resource and which encompasses economic activities that relate to all forest ecosystem services [11] (p. 4).

\subsection{Low Carbon Transitions}

Low carbon transitions are substantial changes in the systems that serve society, so that these systems have less impact on the climate. One such system is housing. According to the International Energy Agency and the United Nations Environmental Program, 28\% of the $\mathrm{CO}_{2}$ emissions related to buildings originate from the use of different materials, with most of the emissions coming from cement and steel manufacturing [12] (p. 43). The International Energy Agency therefore suggests that a change towards bio-based materials would have the potential to reduce the carbon emissions originating from the use of materials in buildings [12] (p. 46). This suggestion is supported by findings in the literature [13-16].

In Sweden, the building and real estate sectors produce approximately $21 \%$ of total greenhouse gas emissions [17]. Of these emissions, $40 \%$ are directly connected to newly built housing and building renovations. Although total emissions from the building and real estate sector decreased during the period between 1993 and 2016, the contribution from the construction of new housing and building renovations has remained constant [17]. One part of the Swedish housing system that could decrease its carbon emissions is the multi-story buildings sector. Approximately $85-90 \%$ of the multi-story buildings in Sweden are built around a concrete or steel frame, while the remaining 10-15\% are built around a wooden frame [18]. A wooden multi-story building (WMB) is a building with more than two storeys and a mainly wooden frame. Building multi-story buildings with wood is a relatively new technique, serving as an alternative to the dominant steel and concrete techniques [19].

\subsection{Needs for Social Acceptance-Research Aim with Focus on Consumers}

Social acceptance among different stakeholder groups will influence the implementation of a low carbon transition [5]. For example, in a study of low carbon transitions in the energy system, Wüstenhagen, et al. [20] found that social acceptance could be a constraining factor for establishing renewable energy innovations on the market and enabling a low carbon transition. For the low carbon transition of the FBB, the social acceptance among some stakeholder groups has been studied. For example, Hodge et al. [21] examined how forestry stakeholders (forest owners, the forest industry and environmental non-governmental organisations) have interpreted and perceived the FBB concept. Perspectives on FBB products such as WMBs have been reported for key stakeholder groups, e.g., structural engineers [22], architects [23], contract managers [24] and civil servants [25]. However, consumer perceptions of WMBs have not yet been studied thoroughly, even though their importance in the transition has been emphasised, e.g., by Mustalahti [26]. Little attention has been given to consumer understandings despite the importance of social acceptance of a low carbon housing system. Therefore, the aim of this project is to 
explain how consumer understandings of the forest-based bioeconomy, with a particular focus on wooden multi-story buildings, can influence a low carbon transition.

A system perspective for a low carbon transition to a forest-based bioeconomy is described below. The description is structured in accordance with a multi-level understanding of conditions for transitions influenced by both technological and social development. The approach and conditions for the field survey that was undertaken are then outlined. This is followed by a presentation of the results from the survey, which was intended to capture consumer understandings and acceptance of a technological transition to a bio-based economy in terms of construction materials in residential multi-story buildings. Finally, some conclusions are presented.

\section{Approach-A Theoretical Framework}

A low carbon transition can be explained using socio-technical transition (STT) theory, which states that technology in itself has no function, but acquires a function in social settings [27] (p. 1257). Socio-technical transition takes place when a socio-technical system changes [28]. Socio-technical systems may be tangible, such as wind power stations, but also intangible, such as the skills, routines, behaviours, infrastructures and organisations needed to operate the tangible item [29]. It is through the arrangement of these elements that social functions in society (e.g., road transportation) are fulfilled. Other examples of social functions that are fulfilled through different socio-technical systems are sustenance, communication, mobility, heat and housing [30].

There are various inter-related reasons why socio-technical systems are resistant to change. These include:

- Dependence within systems [28], which can lead to lock-in effects [30];

- Tangible elements of socio-technical system investment costs [28];

- System-bound habits where people adapt their lifestyle to an artefact, such as having a car (ibid.);

- Sunk investments that have been made in the current technology and socio-technical system, making it unfavourable to invest in new technology (ibid.);

- Companies also tend to stick to established technologies because of advantages created through economies of scale and because of knowledge about the current technology (ibid.).

When a change in a socio-technical system occurs, it is called a socio-technical transition $[27,30]$. The overall dynamic of such transitions can be described through the analytical framework of the multi-level perspective (MLP). This consists of three analytical and heuristic levels, which are closely linked to each other [27]. The MLP describes socio-technical transitions as nonlinear processes, which emerge as a result of developments at three levels (Figure 1). These levels are: (1) niches, where radical innovation takes place; (2) the socio-technical regime, which upholds the stability of the existing system as it is and where established practices and rules are located; and (3) the socio-technical landscape, which is the context influencing the other two levels [31]. At higher levels of the MLP, more actors are more strongly linked to each other in norms reflected in institutional arrangements, resulting in system stability [31]. 


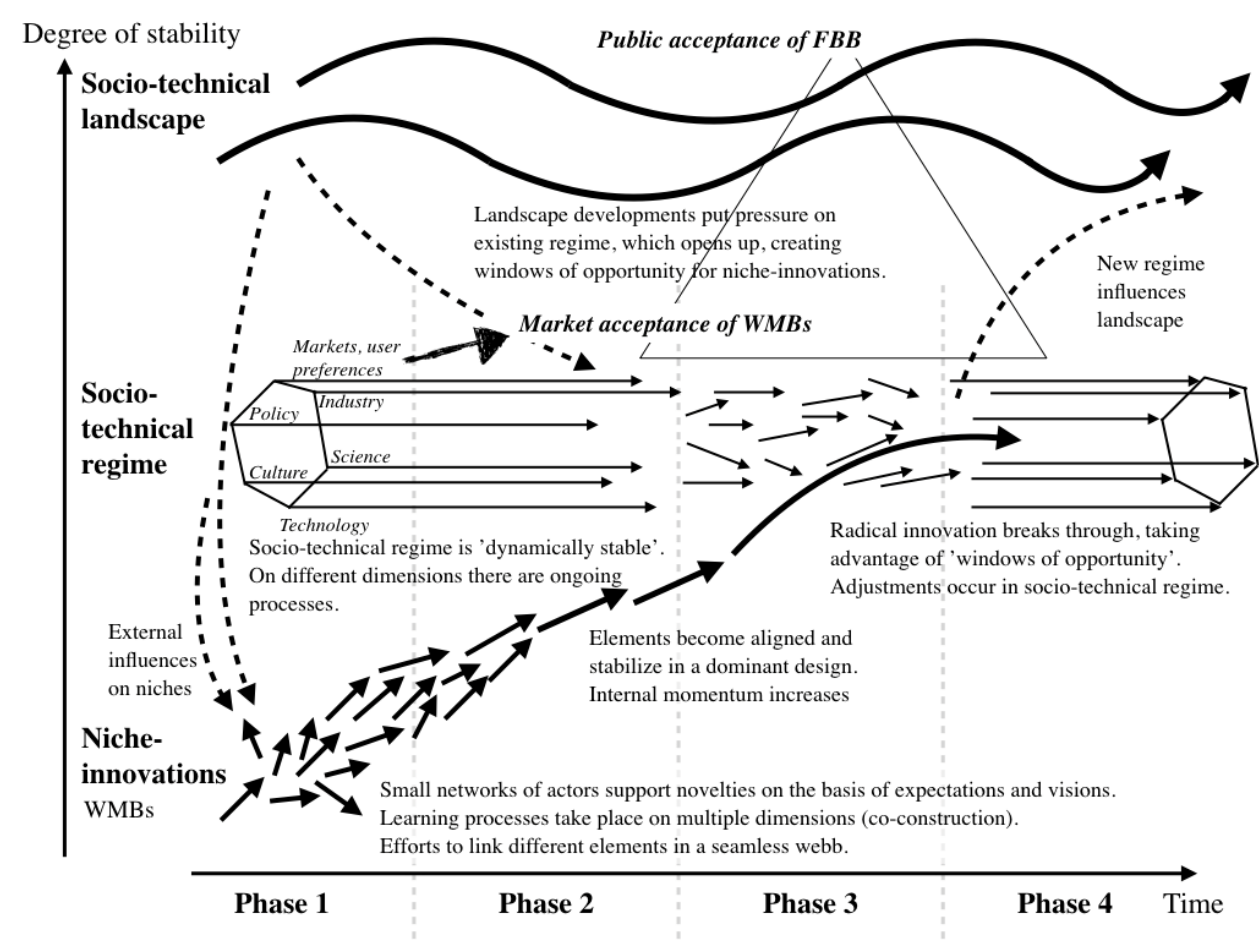

Figure 1. Overview of the theoretical framework, a multi-level perspective theory on pathways for socio-technical transitions and the role of social acceptance, constructed with inspiration from [32] (p. 226) and [20] (p. 2684).

In this study, the system of housing in Sweden represented the socio-technical system, while the socio-technical regime was the dominant multi-story building technique that uses steel and concrete as building materials. The niche innovation was represented by WMBs, with FBB being the change at the socio-technical landscape level (level 3) that influences the other levels of the MLP (Figure 1).

One criticism of using the MLP approach to assess socio-technological change is that it does not include reciprocal influential powers between levels in the MLP [33] (p. 62). This is where the societal, market and consumer dimensions of social acceptance can offer additional explanatory value. Moreover, the limitations in reciprocal influence between the levels in the MLP model serve as a visual representation of system-bound inertia.

\subsection{Social Acceptance}

There are several reasons why social acceptance could be important when seeking to establish low carbon innovations on the market. Public acceptance is needed to implement low carbon policies [30], while customer acceptance is needed for low carbon innovations to take place on the market [31]. In the renewable energy sector, the importance of social acceptance has become increasingly recognized. Ambitious political targets have been set by several governments since the 1980s to increase the amount of renewable energy offered on the market. Despite some success, social acceptance of renewable energy innovations has been identified as a constraining factor for market implementation of these innovations [20].

The three dimensions of social acceptance are socio-political acceptance, community acceptance and market acceptance. Socio-political acceptance concerns the acceptance of technologies and policies, and is the most general level of the social acceptance triangle (Figure 1). The socio-political acceptance level is made up of three groups; the public, key stakeholders and policymakers. An example of an issue that these three groups might handle is general acceptance in society of wind power parks [20]. Community acceptance is a more local level of acceptance, involving local stakeholders (e.g., residents or local authorities) affected by renewable energy innovations in specific places. Market acceptance 
primarily concerns market adoption of renewable energy innovation and involves endconsumer acceptance, but also investor and intra-firm acceptance [20].

Previous studies on FBB have focused on socio-political acceptance by key stakeholder groups [21]. However, several key aspects of the social acceptance part of the model still remain unexplored. Therefore, this study focused on the market acceptance of WMBs and FBB by consumers in Sweden.

\subsection{Dynamics of the Multi-Level Perspective}

Socio-technical transitions are the result of interactions between processes on different levels of the MLP diagram [31]. These transitions can be described as three steps of a general pattern. The first step is when a niche innovation builds up internal momentum. The second step relates to changes at the landscape level that create pressure on the sociotechnical regime. These changes lead to the third step, where destabilisation of the regime creates windows of opportunity for the niche innovation.

The MLP stresses that transitions are not initiated by a single actor, cause or driver, but rather by interconnected processes in multiple dimensions that reinforce each other and create transitions [31]. Socio-technical transition theory provides information about how actors influence the implementation of specific low-carbon options. The influence can either be hindering or stimulating and can be traced by applying the MLP to STT theory. According to Geels, Berkhout and Van Vuuren [5], MLP studies in such cases as this typically analyse developments in the recent past to help identify drivers and barriers of low-carbon innovations and transition pathways in the present. Examples of areas where low carbon transitions have been studied using the MLP approach include electricity systems [34,35], energy systems [36], transportation [37] and the building sector [38,39].

\section{Materials and Methods}

The bioeconomy is frequently perceived as an alternative system to the current unsustainable use of resources [26]. Changes to production and consumption stages are key to achieving the United Nations Sustainable Development Goals (SDGs). In the present study, particular interest was devoted to consumption aspects and the role of consumers in development of economic systems that support sustainable development (https:/ / perform-bioeconomy.info/, accessed on 6 July 2021. The study was part of a project on the bioeconomy conducted by researchers in six European countries.

Transition to a bioeconomy in this study was envisaged to be a low carbon transition and the study object was the FBB, an important part of the Swedish bioeconomy. A widely held belief within the forest industry is that growing forests store carbon and that the carbon remains within constructions when the trees are processed into wood and used for construction. Based on the carbon storage capacity of sustainably managed forests, the forest industry argues that the FBB can be seen as a low carbon transition [40,41]. Therefore, the respondents in the present study were asked if they were familiar with how forests store carbon.

For a low carbon transition to take place, a low carbon innovation must be known to citizens, but also accepted on the market and by consumers. To analyse the social acceptance of consumers, i.e., market acceptance, the respondents in this study were asked about their perceptions of the FBB. Wooden multi-story buildings were chosen as an example of a product representing the FBB, mainly because of their capacity to store carbon. To analyse market acceptance of the $\mathrm{FBB}$, the respondents were asked about their perceptions of the niche innovation of WMBs, in contrast to the dominant socio-technical regime in the housing system in Sweden today. A few questions were also aimed at investigating how the respondents perceived the niche innovation of WMBs to affect elements of the socio-technical landscape, such as the climate, nature and the economy.

A questionnaire was developed and used in a field survey to map respondents' understanding of the bioeconomy concept and of the FBB and WMBs in particular. The responses obtained served as the base for an ad hoc investigation of current understandings 
and social acceptance of the FBB in Sweden. Diverse understandings of the bioeconomy among respondents were expected to lead to differing interpretations of the questions in the survey.

\subsection{Definitions}

In this study, the FBB was defined as an economy that mainly uses forest biomass resources, where appropriate. The FBB can therefore be seen as a transition to the use of renewable and sustainably managed forest resources in the whole economy, or part of it. It encompasses economic activities relating to all forest ecosystem services, from forest biomass in the form of wood products to services such as tourism [11]. The respondents were not given a definition of the FBB and instead answered the survey questions based on their personal understanding of the circular economy and the FBB. Thus, respondents may have had any one of the generic components-a biological system, a societal transformation or an innovation-or a combination of these in mind when completing the survey.

In the questionnaire, WMBs were defined as "multi-story buildings with a mostly wooden frame". The number of storeys needed in a building in order for it to be considered multi-story was not defined for the respondents.

\subsection{The Questionnaire}

The questionnaire was divided in four parts (Appendix A). The first part examined how the respondents perceived WMBs in Sweden, with questions and statements about WMBs compared with concrete. The second part of the questionnaire examined how the respondents perceived carbon storage in forests in Sweden. The third part concerned perceptions of the FBB in Sweden. The final part covered personal information and sought the respondent's informed consent to participate in the study.

Developing a questionnaire is an art that offers much scope for error in how the questions are expressed, the possible answers and the scale of close-ended questions. The questionnaire in the present study offered six reply options on a Likert scale: $1=$ Strongly disagree, 2 = Disagree, 3 = Mildly disagree, $4=$ Mildly agree, $5=$ Agree and $6=$ Strongly agree. The benefit of using the Likert scale is the simplicity, but this must be balanced against the shortcomings of uni-dimensional answers on a scale that is not equidistant in the reply options, which may fail to give a true measure of respondents' attitudes [42].

\subsection{Data Collection}

Data were collected at a common location where many general consumers can be found, namely by an IKEA warehouse. The field survey was carried out on 8-9 December 2018 in Uppsala, Sweden's fourth largest city [43]. Passing consumers were invited to participate, and efforts were made to include an age and gender spread among respondents. The consumer selection process can be classified as convenience sampling, which means that the consumers cannot be assumed to represent a larger population (i.e., the Swedish population). Frequency distribution and graphical displays were therefore used to present the results.

Respondents were given the option to fill out the survey in Swedish or English, using the digital Netigate system. They were rewarded with a SEK 50 (USD 5) gift card for a local restaurant. Respondents were also given assistance in understanding the questions by two students (a male and a female). Some 204 respondents completed the questionnaire and another 22 respondents began the questionnaire but did not complete it. The respondents represented approximately $1.4 \%$ of all visitors to IKEA Uppsala during the data collection period [44].

\subsection{Data Analysis}

Understanding of low carbon transition to a bioeconomy is seen as a precursor for social acceptance. In the case of WMBs, it has not previously been studied, which points to the need to explore understandings as conditions for social acceptance. The data collected 
were a snapshot of perceptions from among people in Sweden visiting IKEA in Uppsala during winter 2018 and therefore the work can be regarded as a case study. The data obtained were used to provide an example of social acceptance in the theoretical model used. Descriptive statistics for the 204 responses obtained in the survey were compiled in frequency distribution tables and bar charts.

First, the demographic background of the respondents was assessed (Table 1). Next, the respondents were grouped into two categories ("Yes" or "No") based on their perceived familiarity or knowledge about three different concepts relating to the FBB in order to get a clear overview of respondents knowledge (Table 2). Respondents who selected "Strongly agree" or "Agree" were seen as having knowledge of or familiarity with the bioeconomy concept, while those who selected one of the other four answer categories ("Mildly agree", "Mildly disagree", "Disagree" and "Strongly disagree") were seen as not having knowledge of or familiarity with the concept. "Mildly agree" was not included in the "Yes" category because of the uncertainty associated with that response, since if the respondent had been entirely sure about the meaning of the concept, they would have given a stronger answer.

Table 1. Numbers and percentages of respondents within each demographic category.

\begin{tabular}{ccc}
\hline Demographic Category: & Sub-Category & Per Cent \\
\hline \multirow{3}{*}{ Gender } & Female & $55.9 \%$ \\
& Male & $43.1 \%$ \\
& Other & $1.0 \%$ \\
& Total & $100.0 \%$ \\
\hline \multirow{2}{*}{ Age category } & $18-39$ & $39.7 \%$ \\
& $40-64$ & $44.6 \%$ \\
& $65+$ & $15.7 \%$ \\
& Total & $100.0 \%$ \\
\hline \multirow{3}{*}{ Which of the following best matches your } & Urban & $58.8 \%$ \\
current area of residence? & Suburb & $17.2 \%$ \\
& Rural & $24.0 \%$ \\
& Total & $100.0 \%$ \\
\hline \multirow{2}{*}{ Do you own more than one hectare } & No & $91.2 \%$ \\
$\left(10,000 \mathrm{~m}^{2}\right)$ of land or forest? & Yes & $8.8 \%$ \\
& Total & $100.0 \%$ \\
\hline
\end{tabular}

Table 2. Frequency distribution table of respondents' perceived familiarity with and knowledge about elements and products of the forest-based bioeconomy.

\begin{tabular}{cccc}
\hline Question & $\begin{array}{c}\text { Yes } \\
\text { (Agree and } \\
\text { Strongly Agree) }\end{array}$ & $\begin{array}{c}\text { No } \\
\text { (Strongly Disagree, } \\
\text { Disagree, Mildly } \\
\text { Disagree, Mildly Agree) }\end{array}$ & Total \\
\hline $\begin{array}{c}\text { I am familiar with how } \\
\text { forests store carbon }\end{array}$ & $63.7 \%$ & $36.3 \%$ & $100.0 \%$ \\
$\begin{array}{c}\text { I know the meaning of } \\
\text { forest-based bioeconomy }\end{array}$ & $28.9 \%$ & $71.1 \%$ & $100.0 \%$ \\
$\begin{array}{c}\text { I am familiar with wooden } \\
\text { multi-story buildings }\end{array}$ & $54.9 \%$ & $45.1 \%$ & $100.0 \%$ \\
\hline
\end{tabular}

Some of the questions in the survey were double-barrelled, which is not desirable from a statistical point of view. However, since this was an explorative study rather than a statistical analysis, the responses to the double-barrelled questions were taken to reflect the respondents' general perceptions about the three dimensions of sustainability, environmental, social and economic. Questions 12-15 and 27-34 are not included in this article since they were not needed to fulfil the aim of the article. 


\section{Results}

\subsection{Understandings of Bio-Based Forest Products and Wooden Multi-Story Buildings}

Background information about the respondents (based on section four in the questionnaire) is presented in Table 1. There was a minor skew towards women among the respondents, and the average age of respondents was 46 years of age. Most of the respondents $(75 \%)$ lived in an urban or suburban area. Very few of the respondents $(10 \%)$ were forest owners.

The majority of the respondents were familiar with how forests store carbon (Table 2). However, when the respondents were asked if they knew the meaning of "FBB", most replied that they did not. The respondents were familiar with the ecological processes which could explain the FBB as a low carbon transition, but their knowledge about the low carbon transition itself was limited. Moreover, the respondents seemed to be more familiar with WMBs, a product within the FBB, than with the FBB per se (Table 2).

Knowledge among the respondents about the FBB was assessed for different demographic categories (gender, age, area of residency and land ownership) (Figure 2). The results showed that respondents who were older than 64 years old, lived in a rural area and owned more than one hectare of land were more likely to perceive that they had good knowledge of the FBB than other respondents.

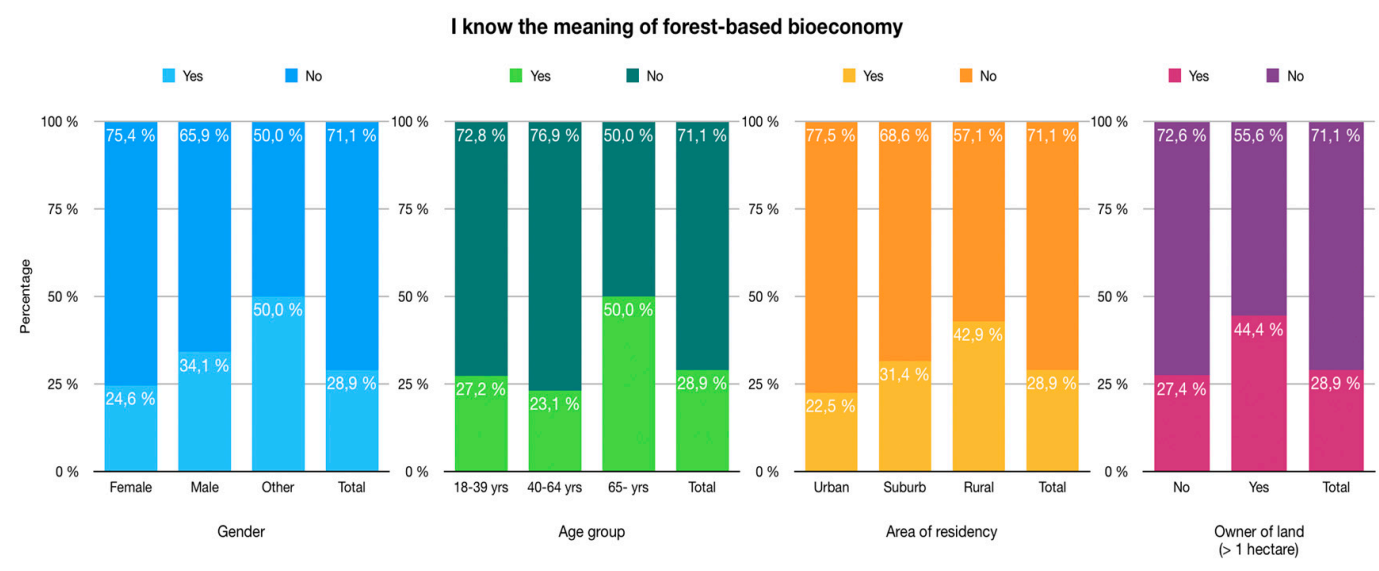

Figure 2. Perceived knowledge about the forest-based bioeconomy among groups of Swedish citizens based on gender, age, area of residence and ownership of land.

The respondents were also asked about their perceptions of the FBB (Figure 3). The frequency distribution of the respondents' responses, divided into Likert answer categories, is shown as a bar chart in Figure 3. A positive percentage indicates that the respondents agreed with the statement, while a negative percentage indicates that the respondents disagreed.

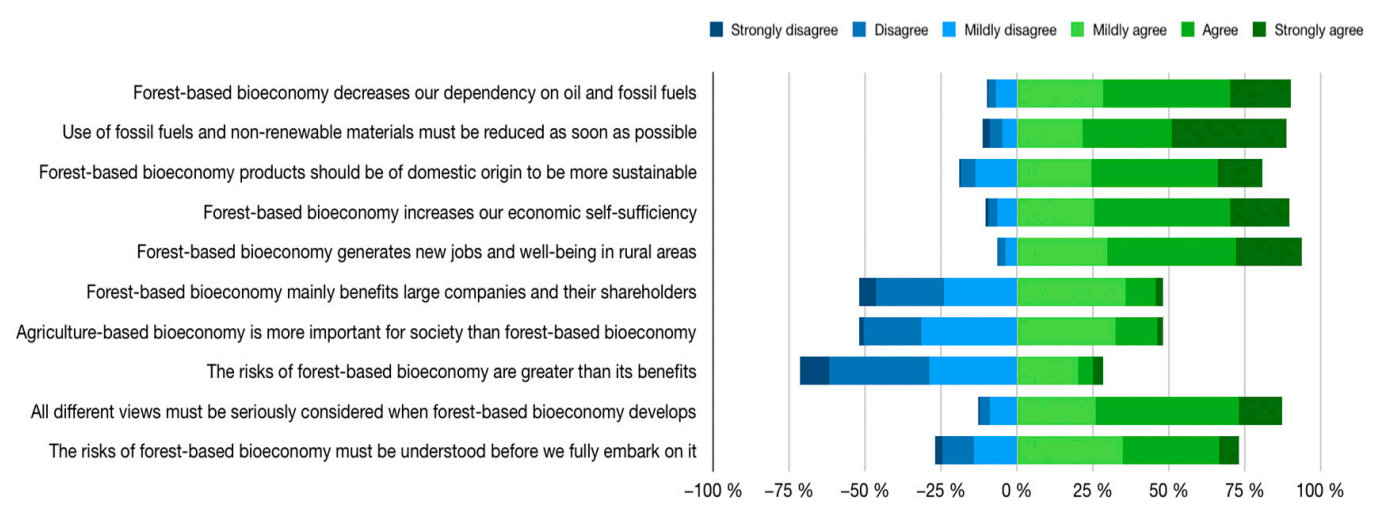

Figure 3. Frequency distribution bar chart of how the respondents perceived the forestbased bioeconomy. 
Despite a lack of knowledge about the meaning of the FBB, the majority of the respondents perceived the FBB to be a low carbon transition (Figure 3). Most of the respondents $(90.2 \%)$ agreed with the statements that FBB decreases the dependency on oil and fossil fuels and that the use of fossil fuels and non-renewable materials must be reduced as soon as possible. This indicates that a majority of the respondents also believed that there is a need for a low carbon transition to take place. However, most respondents $(80.9 \%)$ perceived that a domestic FBB socio-technical transition would be more sustainable than a non-domestic transition, based on the perception among respondents that FBB products are more sustainable if they are produced domestically. The group that knew the meaning of the FBB was in general more positive towards this low carbon transition than the group that did not know about the FBB. A similar analysis was undertaken to investigate whether familiarity with WMBs had any effect on their market acceptance by consumers. Similarly to the findings for socio-political acceptance of FBB, the consumers who were familiar with WMBs were in general more positive towards this low carbon innovation.

Economic value was attributed to the FBB by the majority of the respondents, who saw economic value in terms of economic self-sufficiency (89.7\%) and as a source of new jobs and well-being in rural areas (93.6\%). Apart from the perceived positive economic development in rural areas, however, a large proportion of the respondents (48.0\%) believed that the FBB would mainly benefit large companies and their shareholders. Thus, there seemed to be some disagreement among the respondents on who would benefit the most from the FBB in society. Moreover, there was disagreement about whether the FBB is more important than agriculture.

Regarding the transition to the FBB, the majority of the respondents $(73.0 \%)$ believed that the risks of the FBB must be understood before it is fully implemented and that all different perspectives must be seriously considered for successful implementation. However, most respondents disagreed with the statement that the risks of the FBB are greater than its benefits.

\subsection{Sustainability Aspects of Wooden Multi-Story Buildings}

As shown in Table 2, approximately half of the respondents (54.9\%) were familiar with WMBs. Further analysis (Figure 4) showed that respondents aged 40-64 years, respondents living in a rural area and respondents who owned more than one hectare of land were more familiar with WMBs than other respondents.

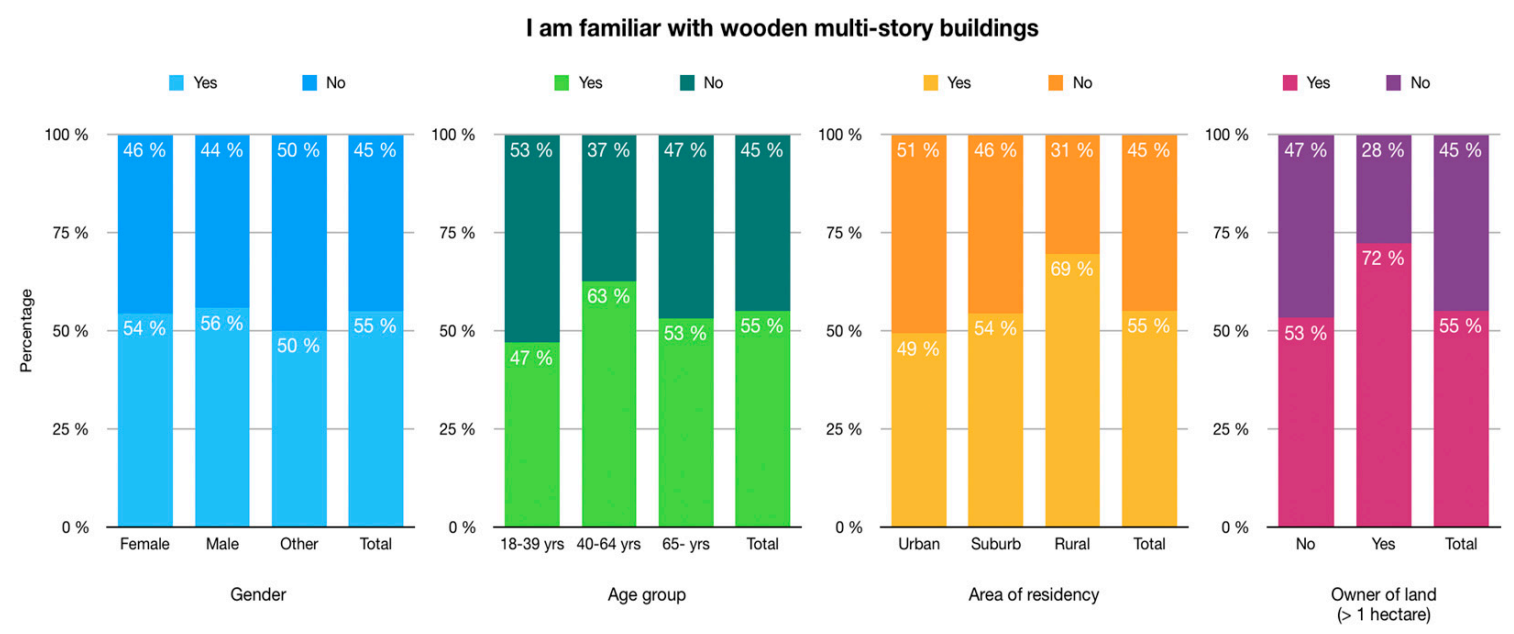

Figure 4. Perceived knowledge about wooden multi-story buildings among groups of Swedish consumers based on gender, age, area of residence and ownership of land.

Figure 5 shows the respondents' responses (agree/disagree) to statements related to wood construction (i.e., WMBs). First, the respondents were asked about their perceptions of the construction and maintenance properties of WMBs. Here, the majority $(65.7 \%)$ 
believed that WMBs are faster and cheaper to build than steel and concrete buildings. A marginal majority $(56.4 \%)$ also believed that WMBs last as long as steel and concrete buildings, do not need more repairs and maintenance and need less insulation than steel or concrete buildings. Thus, some respondents believed that WMBs can offer construction and maintenance benefits compared with the current dominant practice of steel and concrete buildings. However, large proportions of the respondents did not recognise these benefits (Figure 5).

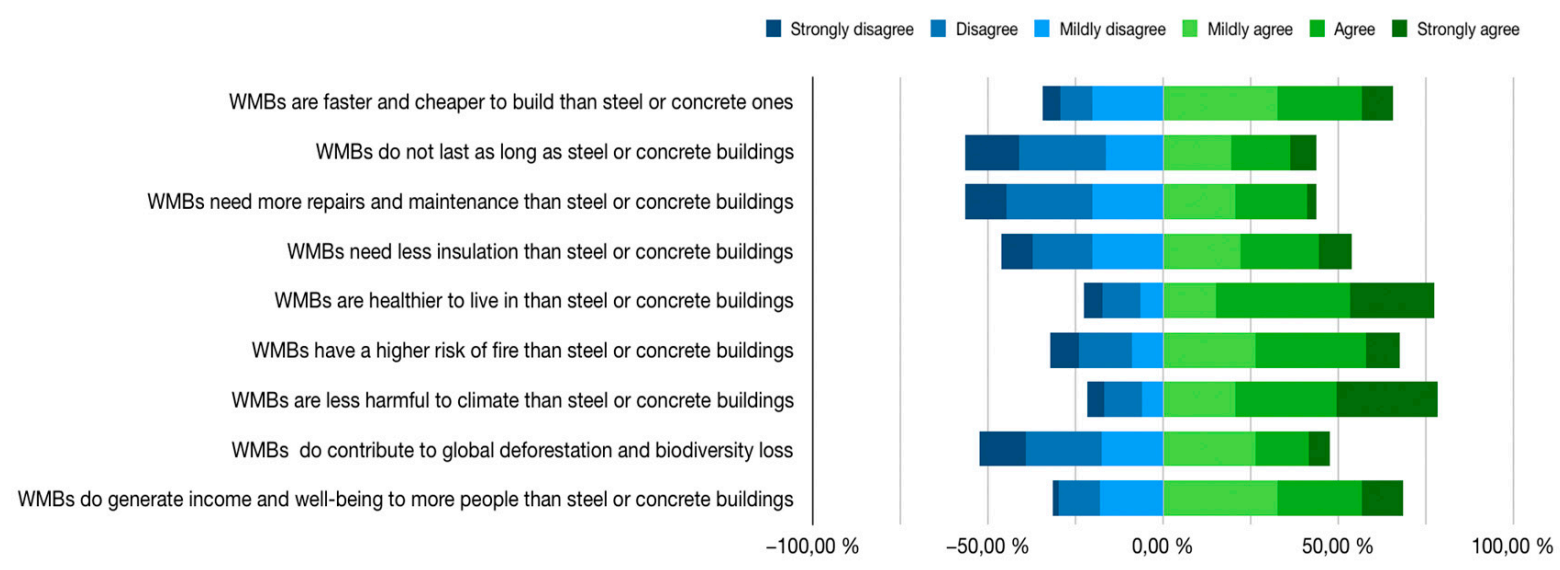

Figure 5. Frequency distribution bar chart of how the respondents perceived wooden multi-story buildings (WMBs) in comparison with steel and concrete buildings.

Most respondents (78.4\%) believed that WMBs are less harmful to the climate than steel and concrete buildings. This means that a majority of the consumers recognised that WMBs offer benefits to the climate that are not provided by the current socio-technical regime. However, approximately half of the respondents (47.5\%) agreed with the statement that WMBs contribute to global deforestation and biodiversity loss, which suggests that WMBs were also seen as a potential threat to environmental aspects other than the climate. A majority $(68.6 \%)$ believed that WMBs generate income and well-being for more people than steel and concrete buildings.

Thus, overall, a majority saw clear economic and social benefits from WMBs compared with steel and concrete buildings but perceived various environmental aspects of WMBs to be both promoting and hindering factors when implementing the low carbon transition of FBB, i.e., as offering climate benefits but causing deforestation and biodiversity loss.

In terms of the housing environment, the respondents were highly positive regarding the health benefits of WMBs compared with the dominant socio-technical regime, as the majority of the respondents (77.5\%) perceived that WMBs were healthier to live in than steel and concrete buildings. WMBs could therefore be seen as having a competitive advantage, assuming consumers associate WMBs with health benefits. In the long run, this could enable a low carbon transition, as the WMB carbon innovation was perceived as offering benefits not only to the climate, but also to the individual, possibly encouraging consumers to invest in WMBs rather than in the current steel and concrete buildings. However, WMBs were also perceived by a majority $(67.6 \%)$ as having a greater risk of fire than steel and concrete buildings, which could be seen as hindering a low carbon transition.

\section{Discussion}

It is claimed that socio-political acceptance by citizens is important when seeking to make sustainability transitions, such as implementing a FBB $[26,45]$. This claim is supported by findings in studies on other low carbon transitions [20,30]. In this study, respondents had a relatively positive view of the FBB, but their in-depth understanding of what the FBB entails was limited. Many respondents interpreted the FBB as a sustainable approach that will play a great or greater role in the future. This positive view is in 
line with that on the bioeconomy held by the forestry stakeholder groups studied by Hodge, Brukas and Giurca [21]. However, Hodge, Brukas and Giurca [21] found that some of the stakeholder groups studied viewed the societal disconnect from nature due to urbanization as a major obstacle to implementing the bioeconomy. In the present study, respondents under the age of 65 years, living in an urban or suburban area and who were not landowners seemed to have a low understanding of the concept of the FBB. On the other hand, most respondents were familiar with the capacity of forests to store carbon. This indicates that there is an understanding of the ecological processes on which the FBB is based. However, it is unknown whether perceived knowledge about the concepts will have an effect on transition to a bioeconomy or FBB.

Limited understanding of the FBB among the public could hinder transition to a low carbon housing system in Sweden and, more widely, to a low carbon Swedish economy [46]. This is primarily because low carbon transitions are not driven by private economic benefits in the same way as socio-technical transitions, but rather are problem-oriented [47] and purposive [48]. The goal with low carbon transitions is to mitigate climate effects, which is a societal good [47]. Private actors therefore have limited incentives to engage in low carbon transitions, so the strong motivating force of private economic benefits is absent [30]. Geels, Sovacool, Schwanen and Sorrell [30] argue that, because of the limited incentives for private actors to engage in low carbon transitions, public policy is needed to create the economic conditions to support successful development and implementation of low carbon innovations on the market. Examples of suitable policy instruments are regulations, taxes, subsidies and standards [30] and the use of social media [49].

However, governments tend to be reluctant to implement low carbon policies, as it is viewed as "bad politics" with a risk of public backlash or bad public opinion figures [50]. The yellow vest movement in France and movements in other parts of the European Union are examples of this backlash [51]. Despite this, Ockwell, Whitmarsh and O'Neill [50] point out that there are examples of low carbon policies that have been politically neutral or positive. According to Giddens [52], the key to success for policymakers when implementing climate change mitigation policies is to gain widespread political support from citizens. Therefore, it seems likely that there is a need to gain widespread political support in order to implement the FBB in the Swedish economy, especially since the present study indicated that respondents who were more familiar with the concept were also more positive towards it.

\subsection{Conditions for a Sustainability Transitions}

The results of this study indicated that there is some market acceptance of WMBs among the Swedish consumers that participated in the survey, even though WMBs are not well established in the marketplace and the concept is not understood and accepted by all. An interesting finding was that respondents who lived in rural areas and were landowners were most familiar with WMBs. However, the data also revealed diverse perceptions of WMBs in the group of respondents surveyed. The respondents were most positive regarding the lower climate impact of WMBs compared with steel and concrete buildings, which could serve as an enabling factor for establishing the niche innovation of WMBs in the socio-technical regime. However, a study by the World Business Council for Sustainable Development [53] found that increased awareness and concern about sustainability issues among consumers is not a guarantee of sustainable consumption. According to Geels [31], this might be due to lack of incentives for consumers to buy a sustainably superior product from a personal perspective, primarily because a sustainable product might offer unsatisfactory quality or cost more.

Similarly, Mark-Herbert, Kvennefeldt and Roos [46] found that residents in WMBs were relatively unaware of living in a WMB and chose their housing based on perceived personal benefits, rather than the sustainability of the construction material. Placing more focus on the function of WMB housing, rather than its sustainability properties, as suggested by Zhao, et al. [54], could perhaps attract more interest in WMBs among 
prospective residents. The results in this study suggested that a majority of the respondents perceived houses built from wood to be healthier, and faster and cheaper to build, than steel and concrete buildings (Figure 5), so WMBs seem to offer benefits directly to consumers as well as to the climate. These benefits imply a perceived higher living standard, health benefits and lower purchasing and living costs for the end-consumer.

More knowledge among the respondents about the FBB and WMBs could increase the socio-political acceptance and serve as an enabling factor for a low carbon transition within the housing system in Sweden. However, the power of consumers to enable such a transition is debatable, as consumers are not responsible for building multi-story houses and are merely able to make a choice among what is offered on a market. Portfolio management decisions, including on construction materials, are made by construction companies [22]. Moreover, consumer acceptance represents only one voice in the transition to a bioeconomy. In this particular empirical context, the development of WMBs is determined by a number of other actors [22-25]. Decisions that are based on previous decisions or experience (path dependency) and strong interconnectedness within the current socio-technical regime can impede transition to a bioeconomy [19,22-24,55].

\subsection{Methodological Reflections}

To our knowledge, the two models that made up the theoretical framework in this study (STT theory and the MLP) have not previously been combined. This theoretical framework placed the focus on the importance of social acceptance in a socio-technical transition but failed to recognise all the dimensions of social acceptance suggested by Wüstenhagen, Wolsink and Bürer [20], as it omitted community acceptance. This is a significant omission, as a low carbon transition such as the FBB cannot proceed without community acceptance of harvesting of forest biomass. There is therefore room for refinement of the theoretical framework in future studies.

One limitation of this study was that the collection of data was not random and that participation was encouraged by offering a gift card. This form of data collection was chosen in order to collect as many answers as possible, since persuading people to spend 10-15 min of their time on a survey is not an easy task. The gift card may have generated a respondent bias, but also more answers $(n=204)$, which is preferable from a scientific point of view. The gift card also attracted people who were not familiar with the university logo used in the survey setting and who were not interested in forests or forestry.

Another limitation is that the questionnaire contained several double-barrelled questions, which could be interpreted in several ways. It is therefore not possible to say how each respondent interpreted each question, but the data obtained provide a general view of the respondents' opinions and provide guidance for future work.

\section{Conclusions}

At present, a forest-based economy (FBB) has been established in the Swedish housing system only to a limited extent, with the niche innovation of wooden multi-story buildings (WMBs) representing approximately $10 \%$ of newly built multi-story houses. This indicates that this niche innovation has gained some momentum but is still not well-established in the Swedish socio-technical regime. This study found some social acceptance of the FBB and WMBs among the consumer group surveyed. However, the results showed some disagreement among the respondents on who would benefit the most from the FBB in society (rural areas or large companies). The majority of the consumers saw clear economic and social benefits with WMBs compared with steel and concrete buildings, as well as climate benefits, but they also perceived WMBs as causing deforestation and biodiversity loss. Overall, the results indicate that social acceptance is not the primary reason why the low carbon transition involving the FBB and WMBs is not more widely adopted in the market today, but rather path dependency and strong interconnectedness within the current socio-technical regime. 
The results of this case study cannot be generalized to other sectors or regions, but consumer perspectives are crucial for future implementation of a wide bioeconomy. This study may provide a foundation for future longitudinal comparisons of changes in public perceptions of the FBB and WMBs. Moreover, social acceptance of the FBB and WMBs could be studied with a more qualitative approach, generating in-depth information about stakeholders' perceptions and practices within a low carbon transition.

Author Contributions: In the article the following contributions were made: Conceptualization, C.B.R., E.N. and C.M.-H.; methodology, C.B.R. and E.N.; validation, C.B.R. and E.N.; formal analysis, C.B.R. and E.N.; investigation, C.B.R. and E.N.; data curation, C.B.R. and E.N.; writing-original draft preparation, C.B.R. and E.N.; writing-review and editing, C.B.R., E.N. and C.M.-H.; visualization, C.B.R. and C.M.-H.; supervision, C.M.-H.; project administration, C.B.R., E.N. and C.M.-H.; funding acquisition, C.B.R. and E.N. All authors have read and agreed to the published version of the manuscript.

Funding: The data gathering in this research was supported by the Swedish Forestry Industries Federation by sponsoring the food tickets at IKEA as an incentive to participate in the survey.

Institutional Review Board Statement: Not applicable. The research project was conducted in agreement with university ethical guidelines, which can be found here https://internt.slu.se/en/supportservices/administrative-support/legal-affairs-data-protection-info-management/info-and-archives$\mathrm{mgmt} / \mathrm{manual}$-research-material/legal-prerequisites/funders-requirements-research-ethics/ (accessed on 6 July 2021).

Informed Consent Statement: Informed consent was obtained from all subjects involved in the study.

Data Availability Statement: Data is available through the link https://stud.epsilon.slu.se/15056/ (accessed on 6 July 2021) and through the link https: / / perform-bioeconomy.info / (accessed on 6 July 2021). The data can also be accessed through contact with the corresponding author.

Acknowledgments: We want to acknowledge Matilda Birath at IKEA Uppsala who made the data collection possible and was always friendly and helpful with our questions and requests. We would also like to thank the anonymous reviewers for constructive feedback in the review process of this article manuscript.

Conflicts of Interest: The authors declare no conflict of interest. The funders had no role in the design of the study; in the collection, analyses, or interpretation of data; in the writing of the manuscript, or in the decision to publish the results.

\section{Appendix A}

Table A1. The complete questionnarie used in the study.

\begin{tabular}{|c|c|c|c|c|c|c|c|}
\hline \multicolumn{2}{|r|}{ UNDERSTANDING URBAN CITIZENS' PERCEPTIONS OF THE BIOECONOMY } & \multirow[b]{2}{*}{ 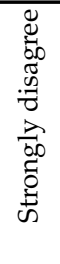 } & \multirow{2}{*}{ 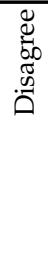 } & \multirow{2}{*}{ 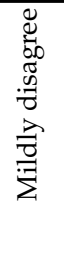 } & \multirow{2}{*}{ 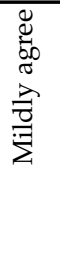 } & \multirow{2}{*}{ 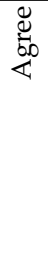 } & \multirow{2}{*}{ 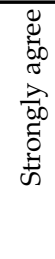 } \\
\hline \multicolumn{2}{|r|}{$\begin{array}{l}\text { This questionnaire is by a European-wide research network on Bioeconomy: PerForm-Perceiving the } \\
\text { Forest-based Sector in the Bioeconomy (wwww.perform-bioeconomy.info (accessed on 6 July 2021)). The } \\
\text { project is funded by the European Forest Institute (wwww.efi.int (accessed on } 6 \text { July 2021)) and facilitated } \\
\text { through network member organisations in Austria/BOKU, Finland/Univ. Helsinki, France/IRSTEA, } \\
\text { Germany/Univ. Freiburg, Italy/Univ. Padova, Russia/Univ. Saint Petersburg, Slovakia/Tech. Univ. Zvolen } \\
\text { and Sweden/SLU. }\end{array}$} & & & & & & \\
\hline \multicolumn{8}{|c|}{$\begin{array}{l}\text { My opinion of multi-storey building with a mostly wooden frame in [COUNTRY] } \\
\text { [Choose what best corresponds your opinion] }\end{array}$} \\
\hline 1 & I am familiar with wooden multi-storey buildings & 1 & 2 & 3 & 4 & 5 & 6 \\
\hline 2 & Are faster and cheaper to build than steel or concrete ones & 1 & 2 & 3 & 4 & 5 & 6 \\
\hline 3 & Do not last as long as steel or concrete buildings & 1 & 2 & 3 & 4 & 5 & 6 \\
\hline 4 & Need more repairs and maintenance than steel or concrete buildings & 1 & 2 & 3 & 4 & 5 & 6 \\
\hline 5 & Need less insulation than steel or concrete buildings & 1 & 2 & 3 & 4 & 5 & 6 \\
\hline 6 & Are healthier to live in than steel or concrete buildings & 1 & 2 & 3 & 4 & 5 & 6 \\
\hline 7 & Have a higher risk of fire than steel or concrete buildings & 1 & 2 & 3 & 4 & 5 & 6 \\
\hline 8 & Are less harmful to climate than steel or concrete buildings & 1 & 2 & 3 & 4 & 5 & 6 \\
\hline
\end{tabular}


Table A1. Cont.

\begin{tabular}{|c|c|c|c|c|c|c|c|}
\hline 9 & Do contribute to global deforestation and biodiversity loss & 1 & 2 & 3 & 4 & 5 & 6 \\
\hline 10 & Do generate income and well-being to more people than steel or concrete buildings & 1 & 2 & 3 & 4 & 5 & 6 \\
\hline \multicolumn{8}{|c|}{ My opinion of storing carbon in forests in [COUNTRY] } \\
\hline 11 & I am familiar with how forests store carbon & 1 & 2 & 3 & 4 & 5 & 6 \\
\hline 12 & Managed forests have great potential to reduce carbon emissions & 1 & 2 & 3 & 4 & 5 & 6 \\
\hline 13 & How forests are being managed can threaten carbon stocks in forests & 1 & 2 & 3 & 4 & 5 & 6 \\
\hline 14 & Land/forest owners need support to maintain and manage forests & 1 & 2 & 3 & 4 & 5 & 6 \\
\hline 15 & Land/forest owners must be compensated monetarily for storing carbon in forests & 1 & 2 & 3 & 4 & 5 & 6 \\
\hline \multicolumn{8}{|c|}{ My opinion of forest-based bioeconomy in [COUNTRY] } \\
\hline 16 & I know the meaning of forest-based bioeconomy & 1 & 2 & 3 & 4 & 5 & 6 \\
\hline 17 & Forest-based bioeconomy decreases our dependency on oil and fossil fuels & 1 & 2 & 3 & 4 & 5 & 6 \\
\hline 18 & Forest-based bioeconomy increases our economic self-sufficiency & 1 & 2 & 3 & 4 & 5 & 6 \\
\hline 19 & Forest-based bioeconomy generates new jobs and well-being in rural areas & 1 & 2 & 3 & 4 & 5 & 6 \\
\hline 20 & Forest-based bioeconomy mainly benefits large companies and their shareholders & 1 & 2 & 3 & 4 & 5 & 6 \\
\hline 21 & Forest-based bioeconomy products should be of domestic origin to be more sustainable & 1 & 2 & 3 & 4 & 5 & 6 \\
\hline 22 & Agriculture-based bioeconomy is more important for society than forest-based bioeconomy & 1 & 2 & 3 & 4 & 5 & 6 \\
\hline 23 & The risks of forest-based bioeconomy are greater than its benefits & 1 & 2 & 3 & 4 & 5 & 6 \\
\hline 24 & The risks of forest-based bioeconomy must be understood before we fully embark on it & 1 & 2 & 3 & 4 & 5 & 6 \\
\hline 25 & All different views must be seriously considered when forest-based bioeconomy develops & 1 & 2 & 3 & 4 & 5 & 6 \\
\hline 26 & Use of fossil fuels and non-renewable materials must be reduced as soon as possible & 1 & 2 & 3 & 4 & 5 & 6 \\
\hline 27 & Environmental regulation limits overall economic development and growth & 1 & 2 & 3 & 4 & 5 & 6 \\
\hline 28 & Humans will be able to solve environmental problems when technology develops & 1 & 2 & 3 & 4 & 5 & 6 \\
\hline 29 & Despite our special abilities, humans are still subject to laws of nature & 1 & 2 & 3 & 4 & 5 & 6 \\
\hline 30 & Humans have the right to modify the natural environment to suit their needs & 1 & 2 & 3 & 4 & 5 & 6 \\
\hline 31 & The balance of nature is very delicate and easily upset & 1 & 2 & 3 & 4 & 5 & 6 \\
\hline 32 & I trust information on forest-based bioeconomy from government officials & 1 & 2 & 3 & 4 & 5 & 6 \\
\hline 33 & I trust information on forest-based bioeconomy from researchers and experts & 1 & 2 & 3 & 4 & 5 & 6 \\
\hline 34 & I trust information on forest-based bioeconomy from environmental and civic organizations & 1 & 2 & 3 & 4 & 5 & 6 \\
\hline \multicolumn{8}{|c|}{ Respondent background information } \\
\hline 35 & Age & & & & & & \\
\hline 36 & Gender & \multicolumn{2}{|c|}{ Female } & \multicolumn{2}{|l|}{ Male } & \multicolumn{2}{|c|}{ Other } \\
\hline 37 & Do you own more than one hectare of land or forest? & \multicolumn{3}{|l|}{ No } & \multicolumn{3}{|l|}{ Yes } \\
\hline 38 & Which of the following best suits your current area of residence? & \multicolumn{2}{|c|}{ Urban } & \multicolumn{2}{|c|}{ Suburb } & \multicolumn{2}{|c|}{ Rural } \\
\hline \multicolumn{8}{|c|}{$\begin{array}{l}\text { Data collected through this survey will be treated confidentially and anonymously for the purposes of the PerForm project, in compliance with the General Data } \\
\text { Protection Regulation (GDPR), Regulation (EU) 2016/679. By filling the questionnaire you give PerForm network staff the permission to process data you } \\
\text { provide for the purposes of the PerForm project. }\end{array}$} \\
\hline \multicolumn{8}{|c|}{ To be completed by the surveyor } \\
\hline \multicolumn{2}{|c|}{ Who collected: } & \multicolumn{3}{|c|}{ Where collected: } & \multicolumn{3}{|c|}{ When collected: } \\
\hline
\end{tabular}

\section{References}

1. Intergovernmental Panel on Climate Change. Summary for Policymakers. In Global Warming of $1.5^{\circ} \mathrm{C}$; An IPCC Special Report on the Impacts of Global Warming of $1.5^{\circ} \mathrm{C}$ above Pre-Industrial Levels and Related Global Greenhouse Gas Emission Pathways, in the Context of Strengthening the Global Response to the Threat of Climate Change, Sustainable Development, and Efforts to Eradicate Poverty; Intergovernmental Panel on Climate Change: Geneva, Switzerland, 2018; p. 32.

2. UN. United Nations Treaty Collection. Available online: https://treaties.un.org $/$ Pages $/$ ViewDetails.aspx?src=IND\&mtdsg_no= XXVII-7-d\&chapter=27\&clang=_en (accessed on 2 December 2019).

3. UNFCCC. UNFCCC eHandbook. Available online: https://unfccc.int/resource/bigpicture/ (accessed on 1 March 2019).

4. Roberts, C.; Geels, F.W.; Lockwood, M.; Newell, P.; Schmitz, H.; Turnheim, B.; Jordan, A. The politics of accelerating low-carbon transitions: Towards a new research agenda. Energy Res. Soc. Sci. 2018, 44, 304-311. [CrossRef] 
5. Geels, F.W.; Berkhout, F.; Van Vuuren, D.P. Bridging analytical approaches for low-carbon transitions. Nat. Clim. Chang. 2016, 6, 576-583. [CrossRef]

6. Mubareka, S.; Jonsson, R.; Rinaldi, F.; Azevedo, J.C.; de Rigo, D.; Sikkema, R. Forest bio-based economy in Europe. In European Atlas of Forest Tree Species; San-Miguel-Ayanz, J., de Rigo, D., Caudullo, G., Houston Durrant, T., Mauri, A., Eds.; Publication Office of the European Union: Luxembourg, 2016.

7. Birner, R. Bioeconomy Concepts; Springer International Publishing: Cham, Switzerland, 2018; pp. 17-38.

8. Corona, P. Forestry research to support the transition towards a bio-based economy. Ann. Silvic. Res. 2015, 38, 37-38. [CrossRef]

9. Priefer, C.; Jörissen, J.; Frör, O. Pathways to Shape the Bioeconomy. Resources 2017, 6, 10. [CrossRef]

10. Staffas, L.; Gustavsson, M.; McCormick, K. Strategies and Policies for the Bioeconomy and Bio-Based Economy: An Analysis of Official National Approaches. Sustainability 2013, 5, 2751-2769. [CrossRef]

11. Winkel, G. Towards a Sustainable European Forest-Based Bioeconomy-Assessment and the Way forward. What Science Can Tell Us 8; European Forest Institute: Joensuu, Finland, 2017.

12. International Energy Agency and the United Nations Environment Programme. 2018 Global Status Report: Towards a Zero-Emission, Efficient and Resilient Buildings and Construction Sector; United Nations Environment Programme: Nairobi, Kenya, 2018.

13. Dodoo, A.; Gustavsson, L.; Sathre, R. Effect of thermal mass on life cycle primary energy balances of a concrete- and a wood-frame building. Appl. Energy 2012, 92, 462-472. [CrossRef]

14. Gong, X.; Nie, Z.; Wang, Z.; Cui, S.; Gao, F.; Zuo, T. Life Cycle Energy Consumption and Carbon Dioxide Emission of Residential Building Designs in Beijing. J. Ind. Ecol. 2012, 16, 576-587. [CrossRef]

15. Nässén, J.; Hedenus, F.; Karlsson, S.; Holmberg, J. Concrete vs. wood in buildings-An energy system approach. Build. Environ. 2012, 51, 361-369. [CrossRef]

16. Perez-Garcia, J.; Lippke, B.; Briggs, D.; Wilson, J.B.; Bowyer, J.; Meil, J. The environmental performance of renewable building materials in the context of residential construction. Wood Fiber Sci. 2005, 37, 3-17.

17. National Board of Housing Building and Planning. Utsläpp av Växthusgaser Från Bygg-och Fastighetssektorn. Available online: https://www.boverket.se/sv/byggande/hallbart-byggande-och-forvaltning/miljoindikatorer---aktuell-status / vaxthusgaser/ (accessed on 18 March 2021).

18. Statistics Sweden. Lägenheter i Nybyggda Ordinära FLERBOSTADSHUS Efter Material i Husens Stomme. År 1995-2019. Available online: https://www.statistikdatabasen.scb.se/pxweb/sv/ssd/START_BO_BO0201_BO0201M/MaterialiStommeFN/ (accessed on 13 May 2019).

19. Mahapatra, K.; Gustavsson, L.; Hemström, K. Multi-storey wood-frame buildings in Germany, Sweden and the UK. Constr. Innov. 2012, 12, 62-85. [CrossRef]

20. Wüstenhagen, R.; Wolsink, M.; Bürer, M.J. Social acceptance of renewable energy innovation: An introduction to the concept. Energy Policy 2007, 35, 2683-2691. [CrossRef]

21. Hodge, D.; Brukas, V.; Giurca, A. Forests in a bioeconomy: Bridge, boundary or divide? Scand. J. For. Res. 2017, 32, 582-587. [CrossRef]

22. Roos, A.; Woxblom, L.; McCluskey, D. The influence of architects and structural engineers on timber in construction-perceptions and roles. Silva Fenn. 2010, 44. [CrossRef]

23. Hemström, K.; Mahapatra, K.; Gustavsson, L. Perceptions, attitudes and interest of Swedish architects towards the use of wood frames in multi-storey buildings. Resour. Conserv. Recycl. 2011, 55, 1013-1021. [CrossRef]

24. Hemström, K.; Gustavsson, L.; Mahapatra, K. The sociotechnical regime and Swedish contractor perceptions of structural frames. Constr. Manag. Econ. 2017, 35, 184-195. [CrossRef]

25. Franzini, F.; Toivonen, R.; Toppinen, A. Why Not Wood? Benefits and Barriers of Wood as a Multistory Construction Material: Perceptions of Municipal Civil Servants from Finland. Buildings 2018, 8, 159. [CrossRef]

26. Mustalahti, I. The responsive bioeconomy: The need for inclusion of citizens and environmental capability in the forest based bioeconomy. J. Clean. Prod. 2018, 172, 3781-3790. [CrossRef]

27. Geels, F.W. Technological transitions as evolutionary reconfiguration processes: A multi-level perspective and a case-study. Res. Policy 2002, 31, 1257-1274. [CrossRef]

28. Geels, F.W. From sectoral systems of innovation to socio-technical systems. Res. Policy 2004, 33, 897-920. [CrossRef]

29. Rip, A.; Kemp, R. Technological change. In Human Choice and Climate Change: Vol. II, Resources and Technology; Rayner, S., Malone, E., Eds.; Battelle Press: Columbus, OH, USA, 1998; pp. 327-399.

30. Geels, F.W.; Sovacool, B.K.; Schwanen, T.; Sorrell, S. The Socio-Technical Dynamics of Low-Carbon Transitions. Joule 2017, 1, 463-479. [CrossRef]

31. Geels, F.W. The multi-level perspective on sustainability transitions: Responses to seven criticisms. Environ. Innov. Soc. Transit. 2011, 1, 24-40. [CrossRef]

32. Geels, F.W. Disruption and low-carbon system transformation: Progress and new challenges in socio-technical transitions research and the Multi-Level Perspective. Energy Res. Soc. Sci. 2018, 37, 224-231. [CrossRef]

33. Berkhout, F.; Smith, A.; Stirling, A. Socio-technological Regimes and Transition Contexts. In System Innovation and the Transition to Sustainability Theory, Evidence and Policy; Elzen, B., Geels, F.W., Green, K., Eds.; Edward Elgar Publishing: Cheltenham, UK, 2004; pp. $48-75$. 
34. Verbong, G.; Geels, F. The ongoing energy transition: Lessons from a socio-technical, multi-level analysis of the Dutch electricity system (1960-2004). Energy Policy 2007, 35, 1025-1037. [CrossRef]

35. Verbong, G.P.J.; Geels, F.W. Exploring sustainability transitions in the electricity sector with socio-technical pathways. Technol. Forecast. Soc. Chang. 2010, 77, 1214-1221. [CrossRef]

36. Matschoss, K.; Heiskanen, E. Innovation intermediary challenging the energy incumbent: Enactment of local socio-technical transition pathways by destabilisation of regime rules. Technol. Anal. Strateg. Manag. 2018, 30, 1455-1469. [CrossRef]

37. Reichenbach, M.; Puhe, M. Flying high in urban ropeways? A socio-technical analysis of drivers and obstacles for urban ropeway systems in Germany. Transp. Res. Part D 2017, 61, 339-355. [CrossRef]

38. Gibbs, D.; O'Neill, K. Rethinking Sociotechnical Transitions and Green Entrepreneurship: The Potential for Transformative Change in the Green Building Sector. Environ. Plan. A Econ. Space 2014, 46, 1088-1107. [CrossRef]

39. Smith, A. Translating Sustainabilities between Green Niches and Socio-Technical Regimes. Technol. Anal. Strateg. Manag. 2007, 19, 427-450. [CrossRef]

40. Swedish Forest Industries Federation. Träboom! Available online: https://www.skogsindustrierna.se/aktuellt/nyheter/2017/0 4/traboom (accessed on 26 April 2020).

41. Swedish Forest Industries Federation. Bygg mer i trä. Available online: https://www.skogsindustrierna.se/vara-asikter/ aktuella_fragor/oka-trabyggandet/ (accessed on 26 April 2020).

42. Bishop, P.; Herron, R. Use and Misuse of the Likert Item Responses and Other Ordinal Measures. Int. J. Exerc. Sci. 2015, 8, 10.

43. Statistics Sweden. Folkmängd, Topp 50. Available online: https://www.scb.se/hitta-statistik/statistik-efter-amne/befolkning/ befolkningens-sammansattning/befolkningsstatistik/pong/tabell-och-diagram/topplistor-kommuner/folkmangd-topp-50/ (accessed on 7 January 2020).

44. Birath, M. (IKEA Marketing Department, Uppsala, Sweden). Personal communication, 2018.

45. Peltomaa, J. Drumming the Barrels of Hope? Bioeconomy Narratives in the Media. Sustainability 2018, 10, 4278. [CrossRef]

46. Mark-Herbert, C.; Kvennefeldt, E.; Roos, A. Communicating Added Value in Wooden Multistorey Construction; IntechOpen: London, UK, 2019.

47. Pearson, P.J.G.; Foxon, T.J. A low carbon industrial revolution? Insights and challenges from past technological and economic transformations. Energy Policy 2012, 50, 117-127. [CrossRef]

48. Smith, A.; Stirling, A.; Berkhout, F. The governance of sustainable socio-technical transitions. Res. Policy 2005, 34, 1491-1510. [CrossRef]

49. Arano Gazal, K.; Montague, I.; Wiedenbeck, J. Factors Affecting Social Media Adoption among Wood Products Consumers in the United States. Bioprod. Bus. 2019, 4, 51-62. [CrossRef]

50. Ockwell, D.; Whitmarsh, L.; O'Neill, S. Reorienting Climate Change Communication for Effective Mitigation. Sci. Commun. 2009, 30, 305-327. [CrossRef]

51. Sengupta, S.; Rubin, A.J. 'Yellow Vest' Protests Shake France. Here's the Lesson for Climate Change. The New York Times, 7 December 2018; p. 1.

52. Giddens, A. Politics of Climate Change; Polity Press: Cambridge, UK, 2009.

53. World Business Council for Sustainable Development. Sustainable Consumption Facts and Trends; World Business Council for Sustainable Development: Geneva, Switzerland, 2008.

54. Zhao, D.-X.; He, B.-J.; Johnson, C.; Mou, B. Social problems of green buildings: From the humanistic needs to social acceptance. Renew. Sustain. Energy Rev. 2015, 51, 1594-1609. [CrossRef]

55. Bengtson, A. Framing Technological Development in a Concrete Context: The Use of Wood in the Swedish Construction Industry. Ph.D. Thesis, Företagsekonomiska Institutionen, Uppsala, Sweden, 2003. 